\title{
Optimization of lipids production by Cryptococcus laurentii 11 using cheese whey with molasses
}

\author{
Rodrigo Fernandes Castanha ${ }^{1}$, Adriano Pinto Mariano ${ }^{2}$, \\ Lilia Aparecida Salgado de Morais ${ }^{1}$, Shirlei Scramin ${ }^{1}$, Regina Teresa Rosim Monteiro ${ }^{3}$ \\ ${ }^{1}$ Embrapa Meio Ambiente, Jaguariúna, SP, Brazil. \\ ${ }^{2}$ NSERC Environmental Design Engineering Chair, Department of Chemical Engineering, \\ École Polytechnique de Montréal, Montreal, QC, Canada. \\ ${ }^{3}$ Centro de Energia Nuclear na Agricultura, Universidade de São Paulo, Piracicaba, SP, Brazil
}

Submitted: August 27, 2012; Approved: September 9, 2013.

\begin{abstract}
This study aimed the optimization of culture condition and composition for production of Cryptococcus laurentii 11 biomass and lipids in cheese whey medium supplemented with sugarcane molasses. The optimization of $\mathrm{pH}$, fermentation time, and molasses concentration according to a full factorial statistical experimental design was followed by a Plackett-Burman experimental design, which was used to determine whether the supplementation of the culture medium by yeast extract and inorganic salts could provide a further enhancement of lipids production. The following conditions and composition of the culture medium were found to optimize biomass and lipids production: $360 \mathrm{~h}$ fermentation, $6.5 \mathrm{pH}$ and supplementation of $\left(\mathrm{g} \mathrm{L}^{-1}\right)$ : 50 molasses, 0.5 yeast extract, $4 \mathrm{KH}_{2} \mathrm{PO}_{4}, 1$ $\mathrm{Na}_{2} \mathrm{HPO}_{4}, 0.75 \mathrm{MgSO}_{4} \cdot 7 \mathrm{H}_{2} \mathrm{O}$ and $0.002 \mathrm{ZnSO}_{4} \cdot \mathrm{H}_{2} \mathrm{O}$. Additional supplementation with inorganic salts and yeast extract was essential to optimize the production, in terms of product concentration and productivity, of neutral lipids by $C$. laurentii 11 . Under this optimized condition, the production of total lipids increased by $133 \%$ in relation to control experiment (from 1.27 to $2.96 \mathrm{~g} \mathrm{~L}^{-1}$ ). The total lipids indicated a predominant (86\%) presence of neutral lipids with high content of 16- and 18- carbon-chain saturated and monosaturated fatty acids. This class of lipids is considered especially suitable for the production of biodiesel.
\end{abstract}

Key words: Cryptococcus laurentii, microbial lipids, cheese whey, sugarcane molasses, biodiesel.

\section{Introduction}

In order to make biodiesel a more sustainable product and economically competitive, there is a constant interest in finding new sources of essential fatty acids and much attention has been given to a class of microorganisms called oleaginous, which are able to produce oils and fats. The combination of these microorganisms with low-cost feedstocks, such as agro-industrial residues, is a promising way to substantially lower the production costs of biodiesel.

A potential source of low-cost feedstock is found in the dairy industry, particularly the whey resulting from the cheese making process. Whey is the liquid remaining after the precipitation and removal of casein from milk (about
$80-90 \%$ of the total volume of milk entering the process) and its composition varies according to milk composition, cheese type, and manufacturing process. Cheese whey contains about $7 \%$ solids, of which $10-12 \%$ is protein, and the remaining fractions are lactose $(74 \%)$, mineral $(8 \%)$ and fat (3\%). This composition represents approximately $55 \%$ of the nutrients originally present in the milk (Karatay and Donmez, 2010). Due to these characteristics, cheese whey has been explored as growth medium for different fermentation processes aiming the production of commodities such as ethanol (Koush et al., 2011) and high-valued chemicals, including poly-3-hydroxybutyrate (PHB), biosurfactants, and lactic acid (Nikel et al., 2005, Rodrigues et al., 2006; Ghasemi et al., 2009). 
As concerning the oleaginous microorganisms, some species of yeasts have been reported to be able to produce lipids. For example, Gill et al. (1977) evaluated the accumulation of lipids by Candida sp. 107 growing on glucose. Evans and Ratledge (1983) studied the growth of Candida curvata on glucose, sucrose, lactose, xylose, and ethanol. More recently, species such as Trichosporon fermentans, Lipomyces starkeyi, and Yarrowia lipolytica showed to be able to utilize crude substrates, including frying oil residue, rice straw hydrolysate, and industrial glycerol, for the production of lipids (Papanikolaou and Angelis, 2002, Huang et al., 2009, Bialy et al., 2011). Examples of yeasts that utilize cheese whey for the production of lipids include Apiotrichum curvatum and Cryptococcus curvatus (Ykema et al., 1988, Takakuwa and Saito, 2010).

Some strains of Cryptococcus are already recognized as good producers of lipids, especially C. curvatus that has been widely studied in fermentations using different substrates, such as hydrolysates of sorghum bagasse and wheat straw, and raw glycerol (Thiru et al., 2011, Yu et al., 2011, Liang et al., 2012). C. albidus was also evaluated for lipid accumulation using volatile fatty acids as carbon source (Fei et al., 2011). However, C. laurentti has not been widely investigated for production of lipids and has been, on the other hand, mainly tested as a postharvest biocontrol agent (Blum et al., 2004).

The use of low-cost crude substrates for the production of bio-products generally demands a supplement with nutrients and labile sources of carbon. For this reason, an additional and important aspect to improve the economics of the production of biodiesel employing oleaginous microorganisms and low-cost feedstocks is to secure a low-cost supplement supply. In countries such as Brazil, South Africa, and India, with important sugar and ethanol production from sugarcane, the by-product molasses is a cheap and abundant material. Molasses contains carbohydrates (glucose, fructose, sucrose) and nutrients and has been studied to be used either as cultivation medium or supplement to microbial production of several bioproducts besides ethanol, such as biopolymer, biosurfactant, and lactic acid (Nitschke et al., 2004, Berwanger et al., 2007, Coelho et al., 2011).

In the context of developing new processes to lower the production costs of biodiesel by combining (i) oleaginous microorganisms, (ii) low-cost feedstock, and (iii) low-cost medium supplement, the aim of the present research was, therefore, the optimization of culture condition and composition for production of $C$. laurentii 11 biomass and lipids in cheese whey medium supplemented with sugarcane molasses.

\section{Materials and Methods}

\section{Cheese whey and molasses}

Four-L cheese whey samples were obtained from Jamava Laticínios (Santa Cruz da Conceição, Brazil) and stored at $4{ }^{\circ} \mathrm{C}$. For the preparation of the fermentation medium, the cheese whey was sterilized at $121{ }^{\circ} \mathrm{C}$ for $15 \mathrm{~min}$ for protein coagulation and then centrifuged at $24953.76 \mathrm{xg}$. The supernatant was collected and used as fermentation medium. Sugarcane molasses was obtained from Fermentec (Piracicaba, Brazil) and stored at $4{ }^{\circ} \mathrm{C}$.

\section{Microorganism, Culture maintenance, and Inoculum preparation}

C. laurentii 11 used in this study was provided by the Department of Microbiology and Biochemistry of the Universidade Estadual Paulista - UNESP (Campus of Rio Claro, Brazil). Laboratory stocks of the culture were grown aerobically at $28 \pm 2{ }^{\circ} \mathrm{C}$ for $72 \mathrm{~h}$ in solid YEPG medium (yeast extract peptone glucose) containing yeast extract $10 \mathrm{~g} \mathrm{~L}^{-1}$, peptone $20 \mathrm{~g} \mathrm{~L}^{-1}$, glucose $20 \mathrm{~g} \mathrm{~L}^{-1}$, and agar $20 \mathrm{~g} \mathrm{~L}^{-1}$. The stocks were maintained at $4^{\circ} \mathrm{C}$ until inoculation of new culture. To prepare the inoculum, three plugs of the culture grown in YEPG medium (laboratory stock) were transferred to an Erlenmeyer flask $(125 \mathrm{~mL})$ containing $50 \mathrm{~mL}$ of seed culture medium, which was composed of $(\mathrm{w} / \mathrm{v})$ : glucose $2 \%$, peptone $1 \%$, and yeast extract $0.5 \%$ and kept at $28{ }^{\circ} \mathrm{C}$ on a rotary shaker incubator at $180 \mathrm{rpm}$ for $24 \mathrm{~h}$.

\section{Production of lipids}

Erlenmeyer flasks $(125 \mathrm{~mL})$ containing $50 \mathrm{~mL}$ of fermentation medium were inoculated with $2 \mathrm{~mL}$ of seed culture and incubated at $28^{\circ} \mathrm{C}$ and $180 \mathrm{rpm}$. Culture condition (fermentation time and $\mathrm{pH}$ ) and composition (concentrations of molasses, yeast extract, and inorganic salts) were optimized using the technique of statistical design of experiments.

A full factorial statistical design (FFD) was used to evaluate the effects of three factors (fermentation time, $\mathrm{pH}$, and molasses concentration) on biomass and lipids production. Each factor was examined at two levels ( -1 for low level and +1 for high level) and at a central point (0). The total number of experiments was $2^{3}+1$, i.e. eight experiments plus a central point (Table 1).

The Plackett-Burman (PB) statistical design was used to determine whether the supplementation of the culture medium by yeast extract and inorganic salts: $\mathrm{KH}_{2} \mathrm{PO}_{4}$, $\mathrm{Na}_{2} \mathrm{HPO}_{4}, \quad \mathrm{MgSO}_{4} \cdot 7 \mathrm{H}_{2} \mathrm{O}, \quad \mathrm{CaCl}_{2} \cdot 2 \mathrm{H}_{2} \mathrm{O}, \quad \mathrm{FeCl}_{3} \cdot 6 \mathrm{H}_{2} \mathrm{O}$, $\mathrm{ZnSO}_{4} \cdot \mathrm{H}_{2} \mathrm{O}$ (Merck ${ }^{\circledR}$, Darmstadt, Germany) could provide a further enhancement of lipids production. Factors and experimental levels of the Plackett-Burman experimental design are presented in Table 2 and the design matrix (PB-16) with coded values for the variables and the results (responses) for dry biomass and total lipids are shown in Table 3. Fermentation time, $\mathrm{pH}$, and molasses concentration were kept at the optimum levels determined by the FFD.

Experiments were conducted randomly and in triplicate. The software Statistica (Statsoft Inc., v. 7.0) was used to analyze the results and the fit quality of the response sur- 
Table 1 - Coded level and real values of the full factorial experimental design with the results (responses) for dry biomass and total lipids.

\begin{tabular}{|c|c|c|c|c|c|}
\hline \multirow[t]{2}{*}{ Run } & \multicolumn{3}{|c|}{ Coded level (real value) } & \multicolumn{2}{|c|}{ Response* } \\
\hline & $\mathrm{pH}$ & Fermentation time $(\mathrm{h})$ & Molasses $\left(\mathrm{g} \mathrm{L}^{-1}\right)^{\mathrm{a}}$ & Dry biomass $\left(\mathrm{g} \mathrm{L}^{-1}\right)$ & Total lipids $\left(\mathrm{g} \mathrm{L}^{-1}\right)$ \\
\hline 1 & $+1(6.5)$ & $+1(360)$ & $+1(100)$ & $13.23 \pm 0.64$ & 1.250 .18 \\
\hline 2 & $-1(5.0)$ & $+1(360)$ & $+1(100)$ & $12.54 \pm 0.23$ & $1.16 \pm 0.06$ \\
\hline 3 & $+1(6.5)$ & $-1(120)$ & $+1(100)$ & $7.22 \pm 0.30$ & $0.75 \pm 0.03$ \\
\hline 4 & $-1(5.0)$ & $-1(120)$ & $+1(100)$ & $6.73 \pm 0.73$ & $0.70 \pm 0.04$ \\
\hline 5 & $+1(6.5)$ & $+1(360)$ & $-1(50)$ & $16.58 \pm 1.47$ & $1.53 \pm 0.12$ \\
\hline 6 & $-1(5.0)$ & $+1(360)$ & $-1(50)$ & $14.75 \pm 2.23$ & $1.05 \pm 0.08$ \\
\hline 7 & $+1(6.5)$ & $-1(120)$ & $-1(50)$ & $8.64 \pm 0.77$ & $0.55 \pm 0.13$ \\
\hline 8 & $-1(5.0)$ & $-1(120)$ & $-1(50)$ & $6.69 \pm 0.34$ & $0.52 \pm 0.04$ \\
\hline 9 & $0(5.75)$ & $0(240)$ & $0(75)$ & $10.66 \pm 0.33$ & $0.79 \pm 0.013$ \\
\hline $\mathrm{CM}^{\mathrm{b}}$ & - & - & - & $4.57 \pm 0.80$ & $1.27 \pm 0.28$ \\
\hline
\end{tabular}

* mean values from triplicate experiments \pm standard deviation.

${ }^{\text {a }} 57 \%$ of total reducing sugars.

${ }^{\mathrm{b}} \mathrm{Control}$ medium composed of cheese whey without molasses supplementation and $\mathrm{pH}$ adjustment. Cultivation was conducted at $28^{\circ} \mathrm{C}$ and $180 \mathrm{rpm}$ for $240 \mathrm{~h}$.

faces was expressed by the coefficient of determination $\mathrm{R}^{2}$ and its statistical significance was determined by an $\mathrm{F}$ test (analysis of variance - ANOVA, $\mathrm{p}<0.05$ ).

\section{Analytical procedures}

\section{Dry biomass}

A 50-mL sample of culture broth was centrifuged for $20 \mathrm{~min}$ at $24953.76 \mathrm{xg}$ and the collected wet cells washed twice with distilled water. Cell dry weight was determined by drying the washed cells to constant weight at $60^{\circ} \mathrm{C}$.

\section{Lipids extraction}

Total cellular lipid was extracted from the dry biomass by the method of Bligh and Dyer (1959) modified. The dry biomass was first treated with $2 \mathrm{M} \mathrm{HCl}$ solution to break the cell wall, subsequently centrifuged (10 $\mathrm{min}$ at $24953.76 \mathrm{xg}$ ) and the supernatant discarded. The biomass was then mixed with $4 \mathrm{~mL}$ distilled water, $10 \mathrm{~mL}$ methanol

Table 2 - Factors and experimental levels of the Plackett-Burman experimental design.

\begin{tabular}{lccc}
\hline Factor $\left(\mathrm{g} \mathrm{L}^{-1}\right)$ & \multicolumn{3}{c}{ Experimental level } \\
\cline { 2 - 4 } & -1 & 0 & +1 \\
\hline Yeast extract & 0.5 & 1 & 1.5 \\
$\mathrm{KH}_{2} \mathrm{PO}_{4}$ & 4 & 7 & 10 \\
$\mathrm{Na}_{2} \mathrm{HPO}_{4}$ & 1 & 2 & 3 \\
$\mathrm{MgSO}_{4} \cdot 7 \mathrm{H}_{2} \mathrm{O}$ & 0.75 & 1.5 & 2.25 \\
$\mathrm{CaCl}_{2} \cdot 2 \mathrm{H}_{2} \mathrm{O}$ & 0 & 0.1 & 0.2 \\
$\mathrm{FeCl}_{3} \cdot 6 \mathrm{H}_{2} \mathrm{O}$ & 0 & 0.01 & 0.02 \\
$\mathrm{ZnSO}_{4} \cdot \mathrm{H}_{2} \mathrm{O}$ & 0 & 0.001 & 0.002 \\
\hline
\end{tabular}

(Mallinckrodt ${ }^{\circledR}$, St. Louis, Missouri, USA) and $5 \mathrm{~mL}$ chloroform (J.T. Baker ${ }^{\mathbb{B}}$, Phillipsburg, USA). The mixture was stirred on a rotary shaker for $2 \mathrm{~h}$ at $220 \mathrm{rpm}$, and further diluted with $5 \mathrm{~mL}$ chloroform and $5 \mathrm{~mL}$ of $1.5 \%$ sodium sulfate (Vetec Química Fina ${ }^{\circledR}$, Duque de Caxias, RJ, Brazil). After separation of the two layers by centrifugation for $2 \mathrm{~min}$ at $173.29 \mathrm{xg}$, the upper aqueous layer containing methanol, water and non-lipid compounds was discarded and the lower chloroform layer filtered on filter paper containing $1 \mathrm{~g}$ anhydrous sodium sulfate and collected in pre-weighed glass vials. This procedure was repeated to extract remaining lipids in the sample. All organic phases collected were mixed and the solvent removed in nitrogen atmosphere. Lipid content was expressed as gram of lipid per liter of fermentation broth.

\section{Fractionation of lipids}

Fractionation of yeast lipids was performed as described by Makri et al. (2010) with modifications. Approximately $100 \mathrm{mg}$ total lipids were dissolved in $1 \mathrm{~mL}$ chloroform and fractionated by using a column $(15 \mathrm{~mm} x$ $100 \mathrm{~mm})$ of $1 \mathrm{~g}$ silica gel $60\left(\mathrm{Merck}^{\circledR}\right.$, Darmstadt, Germany) activated by heating overnight at $100^{\circ} \mathrm{C}$. Successive applications of $100 \mathrm{~mL}$ dichloromethane (Vetec Química Fina ${ }^{\mathbb{B}}$ ), $100 \mathrm{~mL}$ acetone (Vetec Química Fina ${ }^{\mathbb{B}}$ ) and $50 \mathrm{~mL}$ methanol produced fractions containing neutral lipids $(\mathrm{NL})$, glycolipids plus sphingolipids $(\mathrm{G}+\mathrm{S})$, and phospholipids (P), respectively.

\section{Fatty acid composition}

Analysis of fatty acids composition in total lipids and in lipids fractions was performed by Centro de Ciência e Qualidade de Alimentos do Instituto de Tecnologia de Alimentos - ITAL (Campinas, Brazil), according to the methodologies described by Food Standards Agency 
Table 3 - Plackett-Burman design matrix with coded values for the variables and the results (responses) for dry biomass and total lipids $\left(\mathrm{g} \mathrm{L}^{-1}\right)$.

\begin{tabular}{|c|c|c|c|c|c|c|c|c|c|}
\hline \multirow[t]{2}{*}{ Run } & \multicolumn{7}{|c|}{ Factor $^{\mathrm{a}}$} & \multicolumn{2}{|c|}{ Response } \\
\hline & $\mathrm{A}$ & $\mathrm{B}$ & $\mathrm{C}$ & $\mathrm{D}$ & $\mathrm{E}$ & $\mathrm{F}$ & G & Dry biomass $\left(\mathrm{g} \mathrm{L}^{-1}\right)$ & Total lipids $\left(\mathrm{g} \mathrm{L}^{-1}\right)$ \\
\hline 1 & +1 & -1 & +1 & -1 & -1 & -1 & +1 & 19.67 & 2.31 \\
\hline 2 & +1 & +1 & -1 & +1 & -1 & -1 & -1 & 20.15 & 2.25 \\
\hline 3 & -1 & +1 & +1 & -1 & +1 & -1 & -1 & 19.23 & 2.16 \\
\hline 4 & +1 & -1 & +1 & +1 & -1 & +1 & -1 & 19.20 & 2.40 \\
\hline 5 & +1 & +1 & -1 & +1 & +1 & -1 & +1 & 18.92 & 2.96 \\
\hline 6 & +1 & +1 & +1 & -1 & +1 & +1 & -1 & 19.71 & 2.39 \\
\hline 7 & -1 & +1 & +1 & +1 & -1 & +1 & +1 & 19.59 & 2.39 \\
\hline 8 & -1 & -1 & +1 & +1 & +1 & -1 & +1 & 20.14 & 2.65 \\
\hline 9 & -1 & -1 & -1 & +1 & +1 & +1 & -1 & 20.23 & 2.35 \\
\hline 10 & +1 & -1 & -1 & -1 & +1 & +1 & +1 & 19.02 & 2.52 \\
\hline 11 & -1 & +1 & -1 & -1 & -1 & +1 & +1 & 18.39 & 2.70 \\
\hline 12 & -1 & -1 & -1 & -1 & -1 & -1 & -1 & 18.63 & 2.17 \\
\hline 13 & 0 & 0 & 0 & 0 & 0 & 0 & 0 & 18.81 & 2.37 \\
\hline 14 & 0 & 0 & 0 & 0 & 0 & 0 & 0 & 18.64 & 2.36 \\
\hline 15 & 0 & 0 & 0 & 0 & 0 & 0 & 0 & 18.48 & 2.38 \\
\hline 16 & 0 & 0 & 0 & 0 & 0 & 0 & 0 & 18.54 & 2.30 \\
\hline 17 & 0 & 0 & 0 & 0 & 0 & 0 & 0 & 18.24 & 2.62 \\
\hline
\end{tabular}

a(A) yeast extract, (B) $\mathrm{KH}_{2} \mathrm{PO}_{4}$, (C) $\mathrm{Na}_{2} \mathrm{HPO}_{4}$, (D) $\mathrm{MgSO}_{4} \cdot 7 \mathrm{H}_{2} \mathrm{O}$, (E) $\mathrm{CaCl}_{2} \cdot 2 \mathrm{H}_{2} \mathrm{O}$, (F) $\mathrm{FeCl}_{3} \cdot 6 \mathrm{H}_{2} \mathrm{O}$, (G) $\mathrm{ZnSO}_{4} \cdot \mathrm{H}_{2} \mathrm{O}$.

(2002), Hartman and Lago (1973), Firestone (2009) and Horwitz (2010).

\section{Results and Discussion}

\section{Production of lipids}

In the set of experiments arranged according to the full factorial design, the maximum production of biomass $\left(16.58 \pm 1.47 \mathrm{~g} \mathrm{~L}^{-1}\right)$ and lipids $\left(1.53 \pm 0.12 \mathrm{~g} \mathrm{~L}^{-1}\right)$ were obtained in run $5(\mathrm{pH}=6.5 ; 360 \mathrm{~h}$ fermentation time; $50 \mathrm{~g}$ molasses $\left.\mathrm{L}^{-1}\right)$ and the minimum production $(6.69 \pm 0.34 \mathrm{~g}$ biomass $\mathrm{L}^{-1} ; 0.52 \pm 0.04 \mathrm{~g}$ lipids $\left.\mathrm{L}^{-1}\right)$ in run $8(\mathrm{pH}=5.0$; $120 \mathrm{~h}$ fermentation time; $50 \mathrm{~g}$ molasses $\mathrm{L}^{-1}$ ) (Table 1). In control experiment, without supplementation of molasses and $\mathrm{pH}$ adjustment and fermentation time equal to $240 \mathrm{~h}$, biomass and lipids concentrations were $4.57 \pm 0.80 \mathrm{~g} \mathrm{~L}^{-1}$ and $1.27 \pm 0.28 \mathrm{~g} \mathrm{~L}^{-1}$, respectively. In relation to control, the changes in culture condition and composition related to run 5 resulted in an increase of biomass and lipids production by $263 \%$ and $20 \%$, respectively.

The effects of each factor $(\mathrm{pH}$, fermentation time, molasses concentration) on the responses (dry biomass and total lipids) were calculated considering a significance level of 95\% and presented in Pareto charts (Figure 1). A negative effect means that there is a decrease in the response parameter for every increase in the variable and vice-versa. An effect is considered statistically significant if its absolute value is greater than the value indicated by the vertical dotted line in the charts $(p=0.05)$. Thus, based on the calculated effects, the three evaluated factors had effect on the production of biomass, and only $\mathrm{pH}$ and fermentation time had effect on the production of lipids.

Additionally, regression analysis of the results was used to generate response surfaces having biomass and total lipids as functions of the statistically significant factors. The surfaces were used to determine in which ranges of the factors, biomass and total lipids productions were maximized (Figure 2). These ranges were 50 to $75 \mathrm{~g}$ molasses $\mathrm{L}^{-1}, 315$ to $360 \mathrm{~h}$ fermentation time, and $\mathrm{pH}$ of 5.8 to 6.5 .

Fermentation time was the factor with the strongest effect on both responses, and its extension from $240 \mathrm{~h}$ to $360 \mathrm{~h}$ was essential to increase lipids production. Typically, oleaginous yeasts accumulate substantial amount of lipids during the stationary growth phase upon $300 \mathrm{~h}$ fermentation time (Fakas et al. (2009). As to the factor $\mathrm{pH}$, the better production of lipids observed at the high level $(\mathrm{pH} 6.5)$ is also in agreement with other studies (Angerbauer et al., 2008).

Due to the negative effect molasses had on biomass production, cell growth was favored when the concentration of this component was in the lower level, which corresponded to approximately 28.5 to $57 \mathrm{~g} \mathrm{~L}^{-1}$ total reducing sugar. Despite the growth factors and metal ions available 
a)

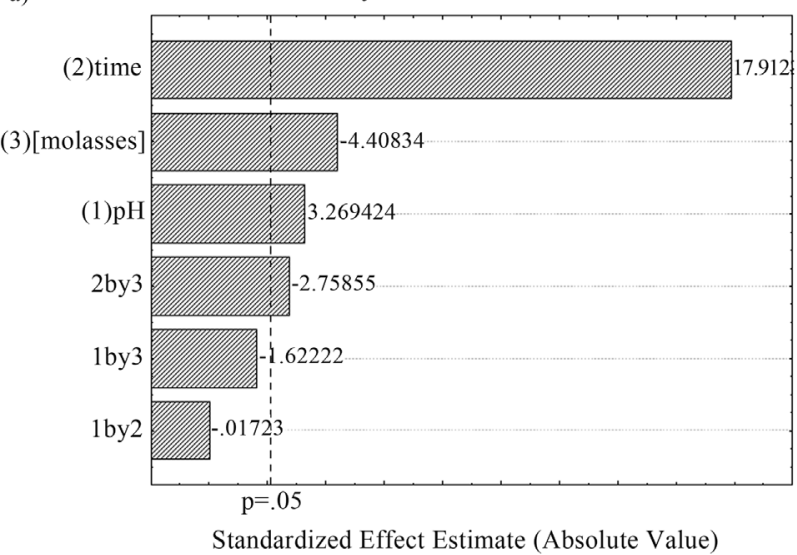

b)

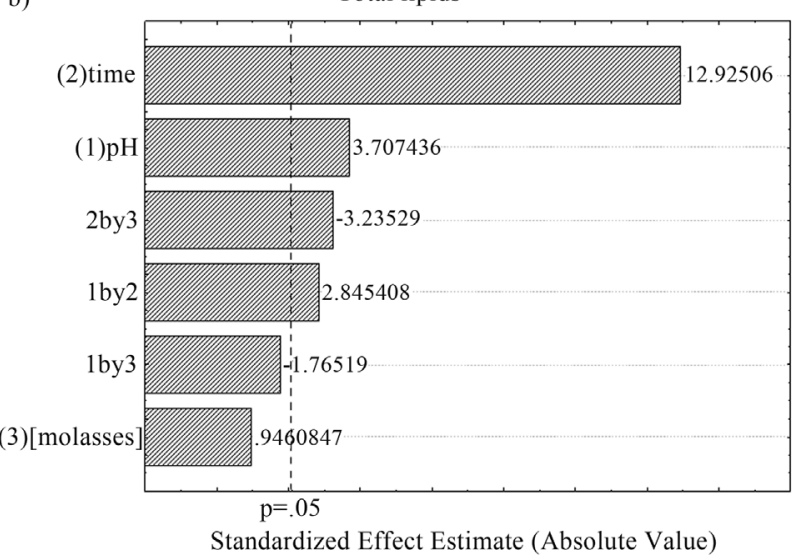

Figure 1 - Pareto chart of the effects of $\mathrm{pH}$, fermentation time, and molasses concentration on (a) biomass production and (b) total lipids production by $C$. laurentti 11 . 1by 2 means interaction between $\mathrm{pH}$ and fermentation time; 1 by 3 means interaction between $\mathrm{pH}$ and molasses concentration; 2 by 3 means interaction between fermentation time and molasses concentration.

in molasses (Crueger and Crueger, 2000), the high concentration of reducing sugar $(57 \%)$ at the high level of supplementation probably inhibited cell growth. It should be noted that, although the variation of molasses concentration from 50 to $100 \mathrm{~g} \mathrm{~L}^{-1}$ had no significant effect on lipids production, the supplementation resulted in an important increase of lipids production (20\%) in comparison with control experiment. For this reason, the lower-bound concentration of $50 \mathrm{~g} \mathrm{~L}^{-1}$ was set as the optimum value. Due to the fact that this rise in lipids production is very probably the maximum improvement possible to be achieved with molasses supplementation, the set of experiments arranged according to the Plackett-Burman design (Table 3) aimed to determine whether the supplementation of the culture medium by yeast extract and inorganic salts $\left(\mathrm{KH}_{2} \mathrm{PO}_{4}\right.$, $\mathrm{Na}_{2} \mathrm{HPO}_{4}, \quad \mathrm{MgSO}_{4} \cdot 7 \mathrm{H}_{2} \mathrm{O}, \quad \mathrm{CaCl}_{2} \cdot 2 \mathrm{H}_{2} \mathrm{O}, \quad \mathrm{FeCl}_{3} \cdot 6 \mathrm{H}_{2} \mathrm{O}$, $\mathrm{ZnSO}_{4} \cdot \mathrm{H}_{2} \mathrm{O}$ ) could provide a further enhancement of lipids production. In these experiments, fermentation time, $\mathrm{pH}$, and molasses concentration were kept constant at their optimum values, respectively, $360 \mathrm{~h}, 6.5$, and $50 \mathrm{~g} \mathrm{~L}^{-1}$.
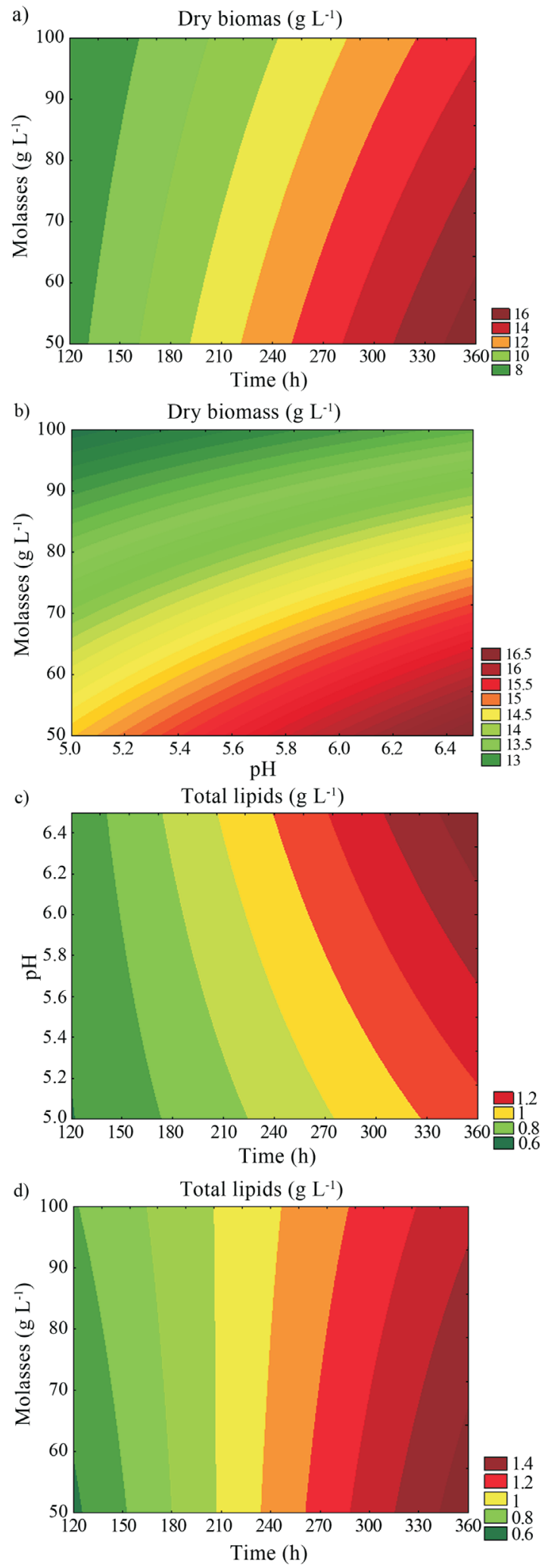

Figure 2 - Response surfaces (a) Dry biomass as a function of molasses concentration and fermentation time $\left(\mathrm{R}^{2}=0.95\right)$; $\mathrm{pH}$ at 5.75. (b) Dry biomass as a function of molasses concentration and $\mathrm{pH}\left(\mathrm{R}^{2}=0.95\right)$; fermentation time at $360 \mathrm{~h}$. (c) Total lipids as a function of $\mathrm{pH}$ and fermentation time $\left(\mathrm{R}^{2}=0.90\right)$; molasses concentration at $75 \mathrm{~g} \mathrm{~L}^{-1}$. (d) Total lipids as a function of molasses concentration and fermentation time $\left(\mathrm{R}^{2}=0.90\right) ; \mathrm{pH}$ at 6.5 . 
Under the different levels of medium components, biomass production varied from 18.24 to $20.23 \mathrm{~g} \mathrm{~L}^{-1}$ and lipids production markedly achieved values between 2.16 and $2.96 \mathrm{~g} \mathrm{~L}^{-1}$ (Table 3) representing an increase by $93 \%$ in relation to the maximum lipids production obtained with molasses supplementation $\left(1.53 \mathrm{~g} \mathrm{~L}^{-1}\right)$. Interestingly, none of the factors had a statistically significant effect on biomass production and only concentration of $\mathrm{ZnSO}_{4} \cdot \mathrm{H}_{2} \mathrm{O}$ positively affected lipids production (Figure 3). Li et al. (2006) also observed increased lipids productions by Rhodosporidium toruloides due to regulation of the $\mathrm{Zn}^{2+}$ concentration. In this manner, the optimum additional supplementation was found to be in the high level for $\mathrm{ZnSO}_{4} \cdot \mathrm{H}_{2} \mathrm{O}$ concentration $\left(0.002 \mathrm{~g} \mathrm{~L}^{-1}\right)$ and in the low level for the other factors.

Overall, the following conditions and composition of the culture medium were found to optimize biomass and lipids production: $360 \mathrm{~h}$ fermentation, $6.5 \mathrm{pH}$ and supplementation of $\left(\mathrm{g} \mathrm{L}^{-1}\right)$ : 50 molasses, 0.5 yeast extract, 4 $\mathrm{KH}_{2} \mathrm{PO}_{4}, 1 \mathrm{Na}_{2} \mathrm{HPO}_{4}, \quad 0.75 \quad \mathrm{MgSO}_{4} \cdot 7 \mathrm{H}_{2} \mathrm{O}$ and 0.002 $\mathrm{ZnSO}_{4} \cdot \mathrm{H}_{2} \mathrm{O}$. Under these optimized conditions, lipids production $\left(2.96 \mathrm{~g} \mathrm{~L}^{-1}\right)$ increased by $133 \%$ in relation to control experiment $\left(1.27 \mathrm{~g} \mathrm{~L}^{-1}\right)$. It is worthwhile to note that lipids production under optimized conditions, however, without molasses supplementation, dramatically dropped to $0.44 \mathrm{~g} \mathrm{~L} \mathrm{~L}^{-1}$. Another important observation is related to lipids productivity $\left(\mathrm{g} \mathrm{L}^{-1} \mathrm{~h}^{-1}\right)$. Although the optimum fermentation time is 5 days longer than in control, the additional supplementation with inorganic salts and yeast extract yielded a more productivity fermentation (55\%). Table 4 presents a summary of the main performance indicators for control and optimized experiments.

\section{Lipids properties}

The fractionation of the lipids indicated that the fatty acid distribution was similar in both control and optimized experiments. Neutral lipids were the predominant fraction ( 72 to $89 \%$ ) followed by glycolipids plus sphingolipids ( 7 to $19 \%$ ) and the phospholipids fraction (4 to $8 \%$ ) (Table 5). This distribution is especially interesting for biodiesel production because neutral lipids are more readily converted to biodiesel than are polar lipids contained in membranes.

The combination of the values regarding neutral lipids fraction and total lipids production yields the following neutral lipids production $\left(\mathrm{g} \mathrm{L}^{-1}\right): 1.1$ (control), 1.1 (opti-

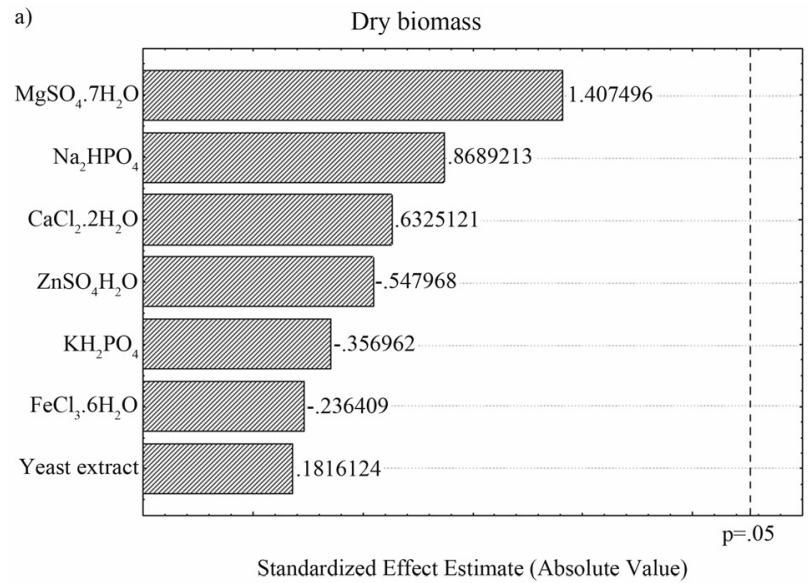

b)

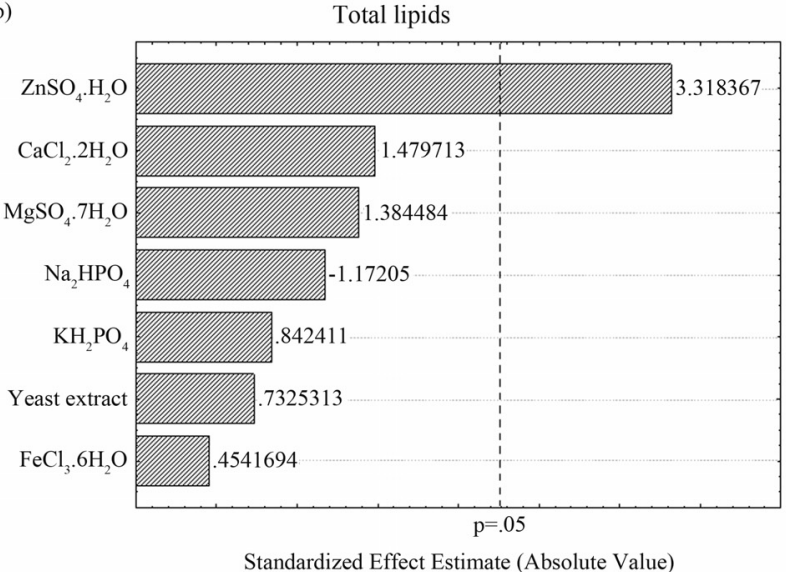

Figure 3 - Pareto chart of the effects of inorganic salts and yeast extract on (a) biomass production and (b) total lipids production by C. laurentti 11 .

mized condition 1), and 2.5 (optimized condition 2). Thus, with the exclusive addition of molasses no gain in terms of neutral lipids production was obtained. In fact, molasses caused the neutral lipids fraction to decrease from $89 \%$ (control) to $72 \%$. As a result, this change in fraction distribution counterbalanced the increase of total lipids production observed under optimized condition 1 . The decrease of the neutral fraction as a consequence of the molasses was observed in other studies and is probably related to the high content of nitrogen compounds in molasses (Zhu et al., 2008, Karatay and Donmez, 2010, Koutb and Morsy (2011), Yan et al., 2011, Liu et al., 2012).

Table 4 - Summary of the main indicators of fermentation performance.

\begin{tabular}{lccc}
\hline Fermentation & $\begin{array}{c}\text { Dry biomass } \\
\left(\mathrm{g} \mathrm{L}^{-1}\right)\end{array}$ & $\begin{array}{c}\text { Total lipids } \\
\left(\mathrm{g} \mathrm{L}^{-1}\right)\end{array}$ & $\begin{array}{c}\text { Lipids productivity } \\
\left(\mathrm{g} \mathrm{L}^{-1} \mathrm{~h}^{-1} 0^{-3}\right)\end{array}$ \\
\hline Control (240 $\mathrm{h}$ fermentation time, without both $\mathrm{pH}$ adjustment and molasses supplementation) & 4.57 & 1.27 & 5.29 \\
Optimized condition 1 (360 $\mathrm{h}$ fermentation time, $\mathrm{pH} 6.5,50 \mathrm{~g}$ molasses $/ \mathrm{L})$ & 16.58 & 1.53 & 4.25 \\
$\begin{array}{l}\text { Optimized condition 2 (360 } \mathrm{h} \text { fermentation time, } \mathrm{pH} 6.5,50 \mathrm{~g} \text { molasses/L plus supplementation } \\
\text { with inorganic salts and yeast extract) }\end{array}$ & 18.92 & 2.96 & 8.22 \\
\hline
\end{tabular}




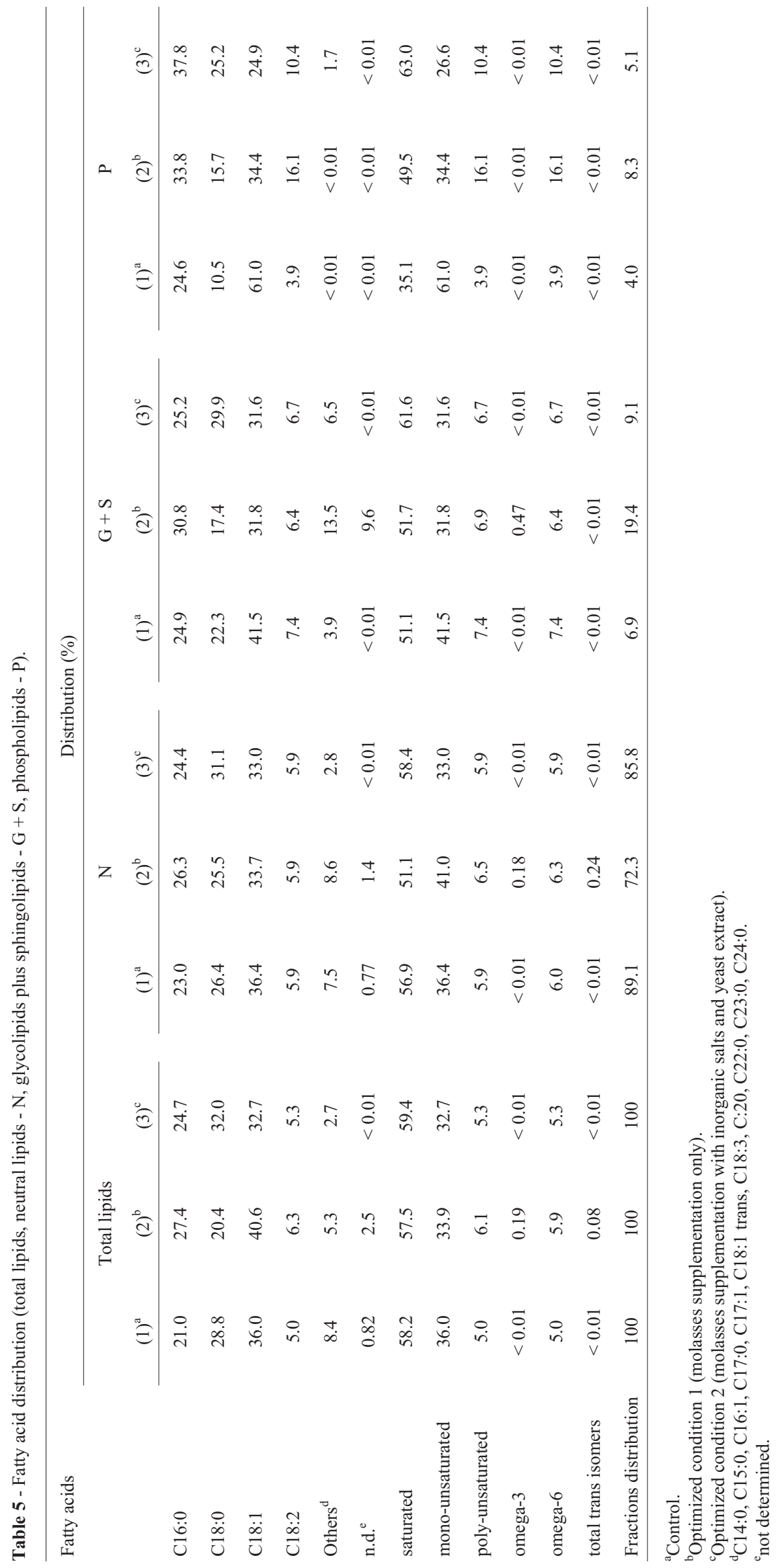


On the other hand, with the additional supplementation with salts and yeast extract (optimized condition 2) the neutral lipids fraction was re-established $(86 \%)$ and similar to control. Thus, only the combination of molasses and chemical supplementation secured an effective improved production of the target lipids fraction essential for biodiesel production. In this case, the total lipids fraction as well as the neutral lipids, glycolipids + sphingolipids, and phospholipids fractions are mainly comprised of 16- and 18-carbon-chain fatty acids, predominantly oleic (C18:1), stearic (C18:0), palmitic (C16:0), and linoleic (C18:2) acid. The high content (59.4\%) of saturated fatty acids lipids and the high cetane number related to them, is an indication that the lipids produced by $C$. laurentii 11 from cheese whey is suitable for the production of a biodiesel with excellent burning characteristics (Mittelbach and Remschmied (2004).

\section{Conclusions}

Additional supplementation with inorganic salts and yeast extract is essential to optimize the production, in terms of product concentration and productivity, of neutral lipids by $C$. laurentii 11 using cheese whey supplemented with sugarcane molasses. Under this optimized condition, the production of total lipids increased $133 \%$ in relation to control experiment (from 1.27 to $2.96 \mathrm{~g} \mathrm{~L}^{-1}$ ). The fractionation of the total lipids indicated a predominant $(86 \%)$ presence of neutral lipids with high content of 16- and 18carbon-chain saturated and monosaturated fatty acids. This class of lipids is considered especially suitable for the production of biodiesel.

\section{Acknowledgments}

This research was supported by Jamava Laticínios, Fermentec, Algae Biotechnology (Brazil), and the National Council for Scientific and Technological Development (CNPq). The authors would like to thank Prof. Dejanira de Franceschi de Angelis (UNESP, Campus of Rio Claro, Brazil) for her generous gift of C. laurentii 11 .

\section{References}

Angerbauer C, Siebenhofer M, Mittelbach M, Guebitz GM (2008) Conversion of sewage sludge into lipids by Lipomyces starkeyi for biodiesel production. Bioresour Technol 99:3051-3056.

Berwanger ALD, Scamparini ARP, Domingues NM, Vanzo LT, Treichel H, Padilha FF (2007) Biopolymer production synthetized by Sphingomonas capsulata, using industrial media. Cienc Agrotec 31:177-183.

Bialy HE, Gomaa OM, Azab KS (2011) Conversion of oil waste to valuable fatty acids using Oleaginous yeast. World $\mathrm{J}$ Microbiol Biotechnol 27:2791-2798.

Blum LEB, Amarante CVT, Valdebenito-Sanhueza RM, Guimarães LS, Dezanet A, Hack-Neto P (2004). Cryptococcus laurentii aplicado em pós-colheita reduz podridões em maçãs. Fitopatologia Brasileira 29:433-436.

Bligh EG, Dyer WJ (1959) A rapid method of total lipid extraction and purification Can J Biochem Physiol 37:911-917.

Coelho LF, De Lima CJB, Rodovalho CM, Bernardo MP, Contiero J (2011) Lactic acid production by new Lactobacillus plantarum LMISM6 grown in molasses: Optimization of medium composition. Braz J Chem Eng 28:27-36.

Crueger W, Crueger A (2000) A Substrate for industrial fermentation. In: Crueger, W., Crueger, A. (eds) Biotechnology: A Textbook of Industrial Microbiology. Panima Publ Corporation, New Delhi, pp 59-62.

Evans CT, Ratledge C (1983) A comparison of the oleaginous yeast Candida curvata grown on different carbon source in continuous and batch culture. Lipids 18:623-629.

Fakas S, Papanikolaoua S, Batsosa A, Galiotou-Panayoutoua M, Mallouchosa A, Aggelis G (2009) Evaluating renewable carbon sources as substrates for single cell oil production by Cunninghamella echinulata and Mortierella isabellina. Biomass Bioenerg 33:573-580.

Fei Q, Chang HN, Shang L, Choi J, Kim N, Kang J (2011) The effect of volatile fatty acids as a sole carbon source on lipid accumulation by Cryptococcus albidus for biodiesel production. Bioresour Technol 102:2695-2701.

Firestone D (2009) Official methods and recommended practices of the American Oil Chemists' Society. In: Royal Society of Chemistry, The composition of foods, 6th ed. Urbana, Cambridge, pp 1-66.

Food Standards Agency (2002) The composition of foods. 6th ed. Royal Society of Chemistry, Cambridge.

Ghasemi M, Najafpour G, Rahimnejad M, Beigi PA, Sedighi M, Hashemiyeh B (2009) Effect of different media on production of lactic acid from whey by Lactobacillus bulgaricus. Afr J Biotechnol 8:81-84.

Gil C, Hall M, Ratledge C (1977) Lipid accumulation in oleaginous yeast (Candida 107) growing on glucose on a single stage continuous culture. Appl Environ Microbiol 33:231239.

Hartman L, Lago RCA (1973) Rapid preparation of fatty acid methyl esters from lipids. Laboratory Practice 22:475-476.

Horwitz W (2010) Official methods of analysis of the Association of Official Analytical Chemists. 18th ed. AOAC, Gaithersburg.

Huang C, Zong MH, Wu H, Liu QP (2009) Microbial oil production from rice straw hydrolysate by Trichosporon fermentans. Bioresour Technol 100:4535-4538.

Karatay SE, Donmez G (2010) Improving the lipid accumulation properties of the yeast cells for biodiesel production using molasses. Bioresour Technol 101:7988-7990.

Koushki MR, Jafari M, Azizi M (2011) Comparison of ethanol production from cheese whey permeate by two yeast strains. J Food Sci Technol http://www.springerlink.com/content/u327568j57576460/.

Koutb M, Morsy FM (2011) A potent lipid producing isolate of Epicoccum purpurascens AUMC5615 and its promising use for biodiesel production. Biomass Bioenerg 35:3182-3187.

Li YH, Liu B, Zhao ZB, Bai FW (2006) Optimized culture medium and fermentation conditions for lipid production by Rhodosporidium toruloides. Chin J Biotechnol 22:650-656. 
Liang Y, Tang T, Siddaramu T, Choudhary R, Umagiliyage AL (2012) Lipid production from sweet sorghum bagasse through yeast fermentation. Renew Energ 40:130-136.

Liu J, Huang J, Jiang Y, Chen F (2012) Molasses-based growth and production of oil and astaxanthin by Chlorella zofingiensis. Bioresour Technol 107:393-398.

Makri A, Fakas S, Aggelis G (2010) Metabolic activities of biotechnological interest in Yarrowia lipolytica grown on glycerol in repeated batch cultures. Bioresour Technol 101:2351-2358.

Mittelbach M, Remschmied C (2004) Biodiesel - The Compreensive Handbook. 1st ed. M. Mittelbach (ed). Graz, Austria.

Nikel PI, Pettinari MJ, Méndez BS, Galvagno MA (2005) Statistical optimization of a culture medium for biomass and poly(3-hydroxybutyrate) production by a recombinant Escherichia coli strain using agroindustrial byproducts. Int Microbiol 8:243-250.

Nitschke M, Ferraz C, Pastore GM (2004) Selection of microorganisms for biosurfactant production using agroindustrial wastes. Braz J Microbiol 35:81-85.

Papanikolaou S, Aggelis G (2002) Lipid production by Yarrowia lipolytica growing on industrial glycerol in a single-stage continuous culture. Bioresour Technol 82:43-49.
Rodrigues LR, Teixeira JA, Oliveira R (2006) Low-cost fermentative medium for biosurfactant production by probiotic bacteria. Biochem Eng J 32:135-142.

Takakuwa N, Saito K (2010) Conversion of beet molasses and cheese whey into fatty acid methyl esters by the yeast Cryptococcus curvatus. J Oil Sci 59:255-260.

Thiru M, Sankh S, Rangaswamy V (2011) Process for biodiesel production from Cryptococcus curvatus. Bioresour Technol 102:10436-10440.

Yan D, Lu Y, Chen YF, Wu Q (2011) Waste molasses alone displaces glucose-based medium for microalgal fermentation towards cost-saving biodiesel production. Bioresour Technol 102:6487-6493.

Ykema A, Verbree EC, Kater MM, Smit H (1988) Optimization of lipid production in the oleaginous yeast Apiotricum curvatum in whey permeate. Appl Microbiol Biotechnol 29:211-218.

Yu X, Zheng Y, Dorgan KM, Chen S (2011) Oil production by oleaginous yeasts using the hydrolysate from pretreatment of wheat straw with dilute sulfuric acid. Bioresour Technol 102:6134-6140.

Zhu LY, Zong MH, Wu H (2008) Efficient lipid production with Trichosporon fermentans and its use for biodiesel preparation. Bioresour Technol 99:7881-7885.

All the content of the journal, except where otherwise noted, is licensed under a Creative Commons License CC BY-NC. 